\title{
Review: Sustainable Water Resources Engineering and Management; Nigerian Perspective
}

\author{
${ }^{1}$ Gana, A. J and ${ }^{2 *}$ Amodu, M. F.
}

${ }^{1}$ Civil Engineering Department, College of Engineering, Landmark University Omu-Aran, Kwara State

${ }^{2}$ Agricultural and Biosystems Engineering Department, College of Engineering, Landmark University Omu-Aran Kwara State

*Corresponding Author E-mail; amodu.matthew@1mu.edu.ng; $\quad$ Tel: 08131642295

Submitted on: 11/05/2021

Accepted on: $27 / 07 / 2021$

\begin{abstract}
Water resources sustainability is essential to life because all living things and some non-living things need it to complete their processes. The water usage is rising, hence pressure on the availability, and some instances rose to crisis level. These pressures were due to population growth, increases in irrigated land, deforestation, soil and land degradation, and wastages. Engineering is one of the majors' components in tackling water resources sustainability. Therefore, this paper reviews the general concepts of sustainable water resources from an engineering and management perspective. The method adopted to realize the aim of the research was a thorough literature review. Engineering has three sub-components, these are Ecological, Economic, and social sustainability. Failure in one of these sub-components is a failure of the component. The literature revealed that Water resources sustainability is a multifaceted discipline therefore, engineering discipline alone would not solve it. However, this paper proffered some recommendations and the way forward. These recommendations are the steps required at the watersheds level, the engineering strategies aspects, and the management strategy. It concluded that a holistic approach where all shareholders will be involved is an ideal approach.
\end{abstract}

Keywords: Sustainable Water Resources, Engineering, Management, Nigerian, Perspectives.

\section{Introduction}

The word "Sustainable" originates from an ancient principle in forestry that is simply not to gain more Timber from the forest than it can generate. This principle for future generations has been valid since 1987. The Burundian commission set up by the United Nations (UN) published their report Brundtland et al (1987) as "Our Common Future" and defined "sustainable development for the first time as development that meets the needs of the present without compromising the ability of the future generation and to meet their needs". Sustainability also comes from the Latin word "Sustainer" meaning "bear". Sustainability can be translated simply as long-term compatibility, support, and maintenance without necessarily compromising future capabilities (Ehiorobo and Ehigiator-Irughe 2017).

In the engineering profession, sustainability is seen in three-dimensional views as illustrated in Figure 1.

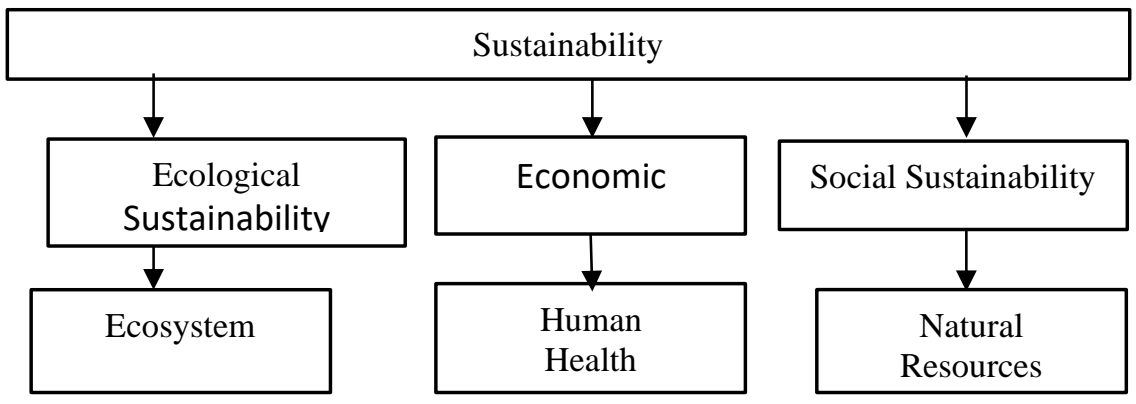

Figure 1: Three-dimensional sustainability in Engineering, Flint (2004) 
Different world scholars equally believe that sustainability is hanging on four itemised pillars:

i) Ecological configuration,

ii) Economic activities and output: that is equity and efficiency,

iii) Good governance and politics,

iv) Performance of education.

Since sustainability embraces all aspects of human life, a trilling question that is always asked is what should be sustained and developed in our environment? A few areas that usually process challenges are: -

a) People: child survival, life expectancy, equal opportunities for everybody, etc.

b) Economy i.e. wealth creation

c) The productive sector, consumption, etc.

d) Good governance, leadership, and politics,(Oni and Excellence-Oluye, 2012).

\section{Water resources engineering}

Water Resouces Engineering is concerned with the protection, development, and efficient management of water resources for beneficial purposes. It involves planning, design, and construction of projects. These are supplies of water for domestic, commercial, public, and industrial purposes. Also, for hydroelectric power. Additionally, for flood prevention measures, control of rivers, and conservation of water resources including prevention of pollution.

\section{Development of water resources}

The development of water resources of any region requires the conception, planning, design, construction, and operation of various facilities to utilize and control water and to maintain water quality. Because each water development project is unique, it is not possible to give a standard solution. The special condition of each project should be tackled through an integrated application of the fundamental knowledge of many disciplines (Ports et al., 2008).

In the process of water resources development, important questions that usually arise are as follows: -

i. How much water is needed?

ii. How much water is available?

iii. How are the requirements satisfied by the supplies?

iv. How is the used-up water disposed of?

\section{Challenges facing water resources engineers}

The inability to identify the essential characteristics of a given water resources problems. The inability to recognize feasible alternatives for resolving water problems. Also, the inability to systematically evaluate all feasible alternatives in terms of the goals and objectives of the decision-makers. Additionally, the inability to present a clear and concise representation of the trade-offs that exist between various alternatives (Ports et al., 2008).

\section{Concepts of water resources in Nigeria}

Nigeria is a country with large green and blue water resources and also with a subsequent long period of the year suitable to produces biomass i.e. over $50 \%$ of the arable land with six months growing seasons and with annual rainfall from 1,100 to $2,700 \mathrm{~mm}$ (Table 1.). The country is also rich in both surface and groundwater resources. The total water resources available in the country are estimated to be 818 billion $\mathrm{m}^{3} / \mathrm{yr}$ (FMWR 2013).

This implies that the country has abundant water resources that are available for use when compared to the total water withdrawal of 44 billion $\mathrm{m}^{3} / \mathrm{yr}$, (FMWR 2013). The country is also blessed with a vast expanse of inland; freshwater and brackish ecosystems. However, their full extent has never been accurately 
LAUTECH Journal of Civil and Environmental Studies

Volume 7, Issue 1; September, 2021

measured due to seasonal variations in rainfall patterns and the total surface area of water bodies in Nigeria, excluding deltas, estuaries, and miscellaneous wetlands that are suitable for rice cultivation, which is estimated to be about 214 billion $\mathrm{m}^{3}$, (Knoema,2017). Despite this, the water resources in the country are unevenly distributed across the different regions of the country with a surplus in some other regions and scarcity in some other regions.

This provides challenges for efficiency in the use and productivity improvement in the water-scarce regions, especially dryland areas of the north where human habitation relies heavily on groundwater resources that usually recharge from freshwater percolation and runoff during the rainy season. Anything that upsets this balance threatens the livelihoods and economy of the people who reside there, Owuor et al. (2016).

Past Government efforts have been focusing on water resources development on a sub-sectorial basis but neglecting to manage it strategically as national resources. Water resources presently worldwide are under extreme pressure. The resulting problems have given rise to many activities that reflect the growing concern and importance according to their sustainable management. In Nigeria, irrigated agriculture accounts for $69 \%$ of the annual blue water withdrawals (Tables 1) from the inland water resources. However, in the Northern region of the country, irrigation systems, and tapping shallow groundwater is low, and freshwater local wetlands are still common with a covering of $30 \%$ of the traditional (Scoones, 1991). This report is a review of water resources management in Nigeria with a focus on the development of a strong Integrated Water Resources Management (IWRM) policy.

Table 1: Water resources in Nigeria

\begin{tabular}{llll}
\hline Water Resources & Year & Amount & Unit \\
\hline Average precipitation & 2005 & 1150 & $\mathrm{~mm} / \mathrm{yr}$ \\
Total precipitation & 2005 & 1062,336 & $\mathrm{Km}^{3} / \mathrm{yr}$ \\
International renewable water resources total & 2005 & 221,000 & $\mathrm{Km} / \mathrm{yr}$ \\
External renewable water resources total & 2005 & 65,200 & $\mathrm{Km} 3 / \mathrm{yr}$ \\
Total water resources & 2005 & 286,200 & $\mathrm{Km}^{3} / \mathrm{yr}$ \\
Irrigation water requirement & 2000 & 1650 & $\mathrm{Km} 3 / \mathrm{yr}$ \\
Water withdrawal & N/A & $\mathrm{N} / \mathrm{A}$ & $\mathrm{N} / \mathrm{A}$ \\
Agriculture & 2000 & 2507 & $\mathrm{Km} 3 / \mathrm{yr}$ \\
Domestic & 2000 & 1687 & $\mathrm{Km}^{3} / \mathrm{yr}$
\end{tabular}

Source: Frenken, (2005); Gana and Osueke, (2012)

\section{Water resources management in Nigeria}

With a population of over 197 million people, Nigeria is the largest country in Africa and accounts for 47 percent of West Africa's populace (World Bank, 2019). The sub-Saharan Nations have relatively abundant water resources which are unevenly distributed with the southern part much cooler of water than the Northern region. Annual precipitation values could be as low as $250 \mathrm{~mm}$ barely lasting a duration of 4months in the north-eastern region. The savannah areas record precipitation of $1000 \mathrm{~mm}-1250 \mathrm{~mm} /$ year. Precipitation in the Niger Delta and tropical rainforest zones spans the longest duration of 8months and has the highest rainfall records of $4000 \mathrm{~mm} /$ year (FGN 2004). 
Table 2: Major inland water resources (including brackish \& freshwater floodplains) of Nigeria

\begin{tabular}{lll}
\hline S/N & Water Body (Major Rivers) & Surface Area (ha) \\
\hline 1 & Anambra river & $1,401,000$ \\
2 & Benue river & 129,000 \\
3 & Cross rivers & $3,900,000$ \\
4 & Imo river & 910,000 \\
5 & Akwa Ibom river & 500,200 \\
6 & Niger river (less kanji \& Jebba lakes) & 169,800 \\
7 & Ogun river & $2,237,000$ \\
8 & Osun river & $1,565,400$ \\
& Subtotal & $\mathbf{1 0 , 8 1 2 , 4 0 0}$ \\
& Major lakes and reservoirs & \\
1 & Lake Chad & 127,000 \\
2 & Kanji lake (manmade) & 127,000 \\
3 & Shiroro lake (manmade) & 31,200 \\
4 & Goronyo lake (manmade) & 20,000 \\
5 & And others (manmade) & 90,000 \\
6 & Flood plains & $3,221,500$ \\
& Other freshwater bodies & \\
1 & Delta and Estuaries, brackish & 858,000 \\
2 & Other (minor reservoirs, fish ponds) & 104,400 \\
3 & Miscellaneous wetlands suitable for rice & $4,108,100$ \\
\hline
\end{tabular}

Source: Frenken, (2005); Gana and Osueke, (2012)

Table 3: Sample of water use patterns by available sources in Nigeria (FGN.2000)

\begin{tabular}{lll}
\hline S/N & Sample of water use patterns by available sources & Percentages $(\%)$ \\
\hline 1 & Spring/stream & 32 \\
2 & Hand-dug well & 27 \\
3 & Rain & 20 \\
4 & River & 16 \\
5 & Pipe bore & 14 \\
6 & Borehole & 14 \\
7 & Vendors & 6 \\
\hline
\end{tabular}

Source: Frenken, (2005); Gana and Osueke, (2012) 
LAUTECH Journal of Civil and Environmental Studies

Volume 7, Issue 1; September, 2021

According to Idu (2015), there is a spatial and temporal variation across the nation with the drying up of shallow wells incident during dry spells in the north, while massive flooding leading to inundation of lowlying wetlands, typifies the southern regions. Adebowale (2018) reported that 69 million Nigerians lack access to safe water notwithstanding, the country's potential for water resources. This disparity will provide a framework useful for identifying the underlying challenges that reduce the quantity and weakens the quality of the country s water resources.

\section{Materials and Methods}

The materials and methods used for this study were through available literature on the topic under discussion. Efforts were made to compare the literature with the present situation of the topic under consideration. A review of some present existing water projects in the country equally assisted in the course of this study.

\section{Results and Discussion \\ Water resource agencies and schemes}

During the 1960s, the government's response to the catastrophic drought scenario marked the turning point of the development and management of water resources in Nigeria. This led to the formation of the Federal ministry of water resources and the river basin development authorities in the mid-1970s and was consolidated by the establishment of the national committee on water resources and the creation of water Boards at state levels in 1981 (Idu, 2015).

a) Before the creation of the Federal Environmental protection Agency (FEPA), was 1987

b) Repetition of functions and structures of the established bodies.

This led to the inability to develop effective water and environmental protection laws and the means to enforce the already existing regulation (Lawrence, 1997), FEPA amongst other agencies merged to form the federal ministry of environment in 1999, creating a vacuum with no effective enforcement of environmental laws and regulations. The irregularity was addressed by establishing the National Environmental Standards and Regulations Enforcement Agency (NESREA), a parastatal of the Federal Ministry of environmental (Ekiye \& Zejiao, 2010).

The Incident of the indiscriminate dumping of Toxic waste by a ship in Koko, Delta State, is triggering a response in creating the said agency in September 1998, which was then charged with the overall responsibility for environmental management and protection. The "National guidelines and standards for environmental pollution" whose major focus was on industrial pollution was published thereafter (Ekiye \& Zejiao 2010).

The start of the operation of these agencies was faced with a lot of challenges, for example, overlapping of roles between the federal, state, and local government on the water resources development Subsequent formation of the eleven Rural Water Supply and Sanitation Agencies (RUWASSA) and the Nigeria Hydrological Service Agency (NHSA) established in 2010 was necessary to ensure rational and efficient management and conservation of the country's water resources. Regardless of the robust structure set up for the development of Nigeria's water resources, there remains the disturbing issue of its inadequacy to match the population's demands. Exhaustion and quality deterioration of this resource can also hinder future expansion resulting in water poverty or distress (Idu, 2015).

\section{Water resources sector in Nigeria and her multi-facet problems}

There are reasons for Nigerian multi-facet water resources problems. A few of these are:

i. Poor investment planning: - poor planning and ineffective coordination or rural water supply programs. Schemes handled by various agencies of Government involved in the provision of water supply schemes have not yielded good and sufficient results. 
ii. Inadequate and Unstable Fiscal Policies and Poor Funding: - This has been noticed among all tiers of Government water projects that are capital intensive. Most of the equipment is imported with foreign funds and loans attached due to low allocations of funds for water resources projects, many of such projects were abandoned in the country, (Council for the Regulation of Engineering in Nigeria, [COREN], 2010).

iii. Inadequate Manpower: - Insufficient relevant manpower, poor remuneration, inadequate training, and high turnover of skilled personnel has affected the performance of the water supply scheme in Nigeria.

iv. Poor Maintenance Policy: - Lack of formal maintenance policy that institutionalizes and also incorporates annual budgetary provisions for maintenance is the reason for the failure of sustainable water supply in the country. In most cases, early decay and breakdown of the equipment, and water shortage are the results.

v. Poor Concept of Water Practice: - Adequate Engineering practice requires that Engineering works should be preceded by thorough investigation and later should be properly designed for optimum performance and efficiency. The construction work should be carried out in a workable manner for such water facilities. This is what is lacking in many water projects in the country.

\section{Strategies for achieving water resources management}

A few strategies for achieving water resources management both at National and International standards are discussed below: -

Identification of watershed problems:- Problems such as flood occurrences, drought, erosion and sediment damages, conservation, development, utilization, disposal of water originating in the watershed should be addressed major problems such as flood-damaged with information on the amount and value of land exposed to the flood hazard in the watershed, frequency of flood occurrence, the significance of small frequent flood or large infrequent flood in total with limitations coupled with other pertinent problems should be given adequate attention and consideration.

\section{Engineering strategies aspects}

Storage, diversion, or lifting of water: This is the first phase of irrigation engineering with the construction of a dam across the river, a sustainable reservoir can be created and water can be stored. Alternatively, if a river perennial and carries sufficient discharges a suitable diversion works such as weirs, barrages can be constructed across the river and water can be diverted to create a canal in places where the groundwater table is high, suitable. Well can be dug and water can be lifted and fed into small channels.

Convergence systems: The stored or diverted water can be conveyed to the agricultural fields through a suitable distribution system. If a proposed project is big, the distribution system will consist of two or more main canals and some distributaries and minors from the canal water can be led to the field through a "watercourse" or "field channel". These field channels take off from the distributaries of minors through modular or non-modular outlets, so that water supply can be regulated.

The second phase includes the design and construction of a suitable canal system, along with various regulatory works such as head regulators, cross regulators, falls, etc. for the efficient working of the canal. In addition to these, suitable cross drainage works such as aqueducts, supper passages, level crossings, bridges, etc. will have to be designed and constructed at places where the canal crosses a natural drain road or a road.

Drainage systems: Proper disposition of excess water by suitable drainage methods is very important for conveyance losses and excess application of water to farm crops which usually result in raising the sub- 
LAUTECH Journal of Civil and Environmental Studies

Volume 7, Issue 1; September, 2021

total water level, the design of a surface and sub-surface drainage system will be of vital importance to maintaining the high productivity of irrigated lands.

Development of hydropower: In rural areas, most of the irrigation projects should be associated with the generation of hydroelectric power either at the dam site or canal falls. If implemented, this will provide more revenue for the country.

Agricultural Aspect: The agricultural aspect deals with a thorough knowledge of the following points before implementation. These are proper depths of the water necessary in a single application of water for various crops, distribution of water uniformly and periodically, capacities of different soils for irrigation water and the flow of water in soils, and reclamation of waste and alkaline land, where this can be carried out through the agency of water.

\section{Management strategy aspects}

For Nigeria to achieve the fuel status of the water resources level, management and leadership principles must be operational. A few examples of such are listed below: -

Visionary Leadership: Nigeria at present needs leaders who would put the economy of the country and other sectors as number one, and follow it up to a logical conclusion. Such leaders would take giant steps to diversify the economy and stop depending on other countries for support. Nigeria has what it takes to become a great nation in terms of water resources that would eliminate menace in the area of poor sanitation, flood, and storm disaster apparent in the country.

Reduction in the level of corruption: With the right kind of leaders, water will flow through all parts of the country without shortage, flood disaster will equally be the story of the past.

Development of achievable goals for water resources: Goals can be used to begin the actual in-depth assessment. Such goals are designed to: -

a. Provide safe and equal access to water supplies needed for domestic, municipal, industrial, agricultural and hydropower uses.

b. Encourage a watershed-based approach in evaluating all water resources issues that are participatory, equitable, and socio-economically sensitive.

c. Develop appropriate water resources policies, institutional arrangements and structures, financial systems, and legal regulatory authorities in other to achieve water resources management.

d. Prevent human health risks due to the spread of water-borne diseases.

e. Reduces discharges of pollutants into surface water and also eliminates contamination of groundwater.

f. Encourage research that would form feedback for social learning and adaptive management.

A properly organised water resources management will ensure:

i. A sound environmental education and community awareness on water quality.

ii. Improved public and private managed irrigation system.

iii. Efficient watershed management

iv. Regulated water supplies.

v. Create employment opportunities.

vi. Effective and safe water harvesting, and

vii. Purposeful networking and collaboration. 


\section{Conclusions}

The prosperity of a nation depends primarily upon the exploitation of its natural resources. Water is one of the most indispensable commodities that man has exploited than any other resource for the sustenance of his life and the ecosystems. Water resources crisis increase in some parts of Nigeria could be attributed to the unsustainable use, population growth, and poor management manifesting in the destruction of ecosystems such as forests, soil degradation, water storage, and water release. In this paper, the highlight is the role engineering component in water resources sustainability. Each component of the tripod pillar of the engineering is equally important any failure in one results in failure in the component. However, water resources being a multifaceted discipline it could better be given a holistic approach for its success. Not only engineering is important other components that are non-engineering are equally important for water resources sustainability. After air the most important natural resource is water and its sustainability is imperative for the continuation of the wellbeing of living and non-living things because water may be required to complete its processes. For example, weathering and soil formation. For better results, the realisation of the multifaceted discipline nature of water resources makes it expedient to give a holistic approach for its sustainability, by involving all stakeholders at different stages.

\section{Recommendations}

\section{Suggested steps towards watershed}

Recognition Phase: The recognition of watershed problems should be carried out by conducting several surveys such as soil surveys, land surveys, agronomic surveys, permanent vegetation surveys, engineering surveys, and socio-economic surveys.

Restoration Phase: This phase follows the recognition phase in which treatment measures should be applied to the critical areas of the problems for restoration.

Protection Phase: The protection phase covers the treated areas which have been restored earlier.

Improvement Phase: The improvement phase covers all areas.

Evaluation: Evaluation should be conducted to accomplished the set objectives such as flood control, sediment control, water supply, and financial return.

\section{References}

Adebowale, N. (2018 March 22nd). 69 million Nigerians lack access to safe water- UNICEF. PREMIUM TIMES

Brundtland, G. H., Khalid, M., Agnelli, S., Al-Athel, S., \& Chidzero, B. J. N. Y. (1987). Our common future. New York, 8.

Council for the Regulation of Engineering in Nigeria, (2010). Book of proceedings: 19th COREN Assembly: Nigeria at 50: challenges of sustainable engineering infrastructural development, National Conference Centre, Abuja, Nigeria 3rd-4th August 2010. https://searchworks.stanford.edu/view/13313119. Accessed 25/06/2021

Ehiorobo, J. O., and Ehigiator-Irughe, R. (2017). Sustainable Environmental Monitoring and Database Development Method for Climate Induced Hazard Management. Nigerian Journal of Environmental Sciences and Technology (NIJEST) Vol, 1(1), 123-130. https://nijest.com/wpcontent/uploads/NIJEST_Published_Papers/NIJEST_Vol_1_No.1_March_2017/123-130_4_Vol-1No.-1_NIJEST.pdf. Accessed 23/06/2021

Ekiye, E., \& Zejiao, L. (2010). Water quality monitoring in Nigeria; Case Study of Nigeria's industrial cities. Journal of American Science, 6(4), 22-28. http://www.jofamericanscience.org/journals/amsci/am0604/04_2270_water_am0604_22_28.pdf. Accessed 23/06/2021

FGN Federal Republic of Nigeria (2004) NATIONAL WATER POLICY. July 2004. http://extwprlegs1.fao.org/docs/pdf/nig158231.pdf 
LAUTECH Journal of Civil and Environmental Studies

Volume 7, Issue 1; September, 2021

FGN Federal Republic of Nigeria (2000). Water supply and sanitation Interim Strategy Notes. November 2000. http://docplayer.net/20806603-Federal-republic-of-nigeria-water- $\quad$ supply-sanitationinterim-strategy-note-November-2000.html. Accessed 27/06/2021

Flint. R. W. (2004). The sustainable development of water resources, University Council on Water Resources Update, Issues vol 127, pgs 48-59. http://www.eeeee.net/sd_water_resources.pdf. Accessed 23/06/2021

FMWR: Federal Ministry of Water Resources (2013). The Project for Review and Update of Nigeria National Water Resources Master Plan. Volume 4. National Water Resources Master Plan 2013. Japan International Cooperation Agency (JICA). $\quad$ https://openjicareport.jica.go.jp/pdf/12146569.pdf

Frenken, K. (Ed.). (2005). Irrigation in Africa in figures: AQUASTAT survey, 2005 (Vol. 29). Food \& Agriculture Org. http://www.fao.org/3/A0232E/a0232e.pdf. Accessed 20/06/2021

Gana. A. J, and Osueke. O. C. (2012). Integrated water resources and waste management. World Journal of Applied Science and Technology, Vol 4, No 2, ISSN 2141-3290, Pgs 301-309, Faculty of Science, University of Uyo, Nigeria.

Idu, A.J. (2015). Threats to Water Resources Development in Nigeria. Journal of Geology \& Geophysics. DOI; 10.4172/2329-6755.1000205

Knoema (2017). Nigeria - Volume of surface water produced internally. https://knoema.com/atlas/Nigeria/Volume-of-surface-water-produced. Accessed 24/06/2021

Lawrence, D. P. (1997). PROFILE: integrating sustainability and environmental impact assessment Environmental Management, 21(1), 23-42. https://www.researchgate.net/profile/David-Lawrence8/publication/226216991_PROFILE_Integrating_Sustainability_and_Environmental_Impact_Assess ment/links/55c244c208aebc967defd8d5/PROFILE-Integrating-Sustainability-and- EnvironmentalImpact-Assessment.pdf . Accessed 12/06/2021

Oni, S. and Excellence-Oluye, N. O. (2012). Leadership and Good Governance: The Nigerian Experience. http://eprints.covenantuniversity.edu.ng/9223/1/Governance\%20and\%20Leadership.pdf. Accessed on 24/06/2021

Owuor, S. O., Butterbach-Bahl, K., Guzha A. C., Rufino M. C., Pelster D. E., Díaz-Pinés, E., Breuer, L. (2016). Groundwater recharge rates and surface runoff response to land use and land cover changes in semi-arid environments. Ecological Processes (2016) 5:16. DOI 10.1186/s13717- 016-0060-6

Ports, M. A., WRE, D., Zimbelman, D., Nanda, S. K., \& Heaney, J. P. (2008). Water Resources Engineering (WRE) Body Of Knowledge (BOK). https://www.aawre.org/sites/aawre.org/files/users/fkim/AAWRE\%20Revised\%20WRE\%20BOK\%20 March\%202009.pdf. Accessed 25/06/2021

Scoones, I. (1991). Wetlands in drylands: key resources for agricultural and pastoral production in Africa Ambio, 366-371. https://www.jstor.org/stable/4313867?casa_token=cGxXfjjroOkAAAAA\%3ALssQeDC3rvnx4u \&seq=1\#metadata_info_tab_contents. Accessed 20/06/2021

World Bank (2019). Nigeria Digital Economy Diagnostic Report 2019 The World Bank Group. 1818 H Street NW, Washington, 20433. https://documents1.worldbank.org/curated/en/387871574812599817/pdf/Nigeria-Digital-Economy Diagnostic-Report.pdf. Accessed 30/06/2021 